\title{
Kamratrespons som formativ bedömning för lärande
}

\author{
En analys av kamratresponstexter på lärarutbildningen
}

Jennie Sivenbring*

Institutionen för pedagogik kommunikation och lärande, Göteborgs universitet

I denna artikel studeras kamratrespons, som ett sätt att arbeta med formativ bedömning för att möjliggöra ett utvidgat lärande; ett lärande som avser både den som ger och tar emot responsen. Kamratrespons används ofta i högre utbildning med motiveringen att det är ett kostnadseffektivt verktyg som kan ge pedagogiska vinster. Genom att analysera formativa råd och motiveringar i ett antal responstexter skrivna av studenter som går sin första termin på lärarprogrammet, studeras vilka pedagogiska vinster som möjliggörs och vad det är som villkorar att dessa möjliga vinster kan nås.

Nyckelord: kamratrespons, formativt lärande, feedback, pedagogiska vinster, lärarutbildning

\section{INLEDNING}

Kamratrespons är en metod som förekommer allt oftare i högre utbildning (Hanrahan \& Isaacs, 200I; McGarr \& Clifford, 2013; Snowball \& Mostert 2013; Topping, 2005). Motiven för att använda sig av denna typ av formativa tekniker kan uttryckas som att de förutom att vara kostnadseffektiva, då de placerar traditionella läraruppgifter i händerna på studenter, också kan bidra till pedagogiska vinster. Dessa motiv används också som incitament för att använda sig av kamratrespons i den kärnkurs på lärarprogrammets första termin som bildar utgångspunkt för denna studie. Vilka de pedagogiska vinsterna eventuellt skulle kunna vara, specificeras dock inte i kursplan eller kursguide $^{1}$. I denna text analyseras ett antal autentiska kamratresponstexter skrivna av studenter i nämnda kurs. Syftet är att synliggöra vilka pedagogiska vinster som möjliggörs genom kamratrespons. Inledningsvis presenteras resonemang kring kamratrespons som formativ bedömning och en kort översyn av vad forskningen tidigare har bidragit med på området.

\section{KAMRATRESPONS OCH PEDAGOGISKA VINSTER}

I den här texten betraktas kamratrespons som en möjlig väg att skapa förutsättningar för kollaborativt lärande. När den internationella forskningen talar om olika former av kamratrespons används begreppen: peer learning, peer assessments, eller peer tutoring. Topping (2005) definierar peer learning som "the acquisition of knowledge and skill through active helping and supporting among equals or matched companions" (ibid:63I). Definitionen avser således kunskaper och kompetenser som kan nås genom att aktivt handleda, hjälpa och stötta någon som befinner sig i liknande kunskaps- och förståelsesituation.

* Författarkontakt: Jennie Sivenbring jennie.sivenbring@gu.se

Artiklar og reflektioner är kollegialt granskade. Övriga bidragstyper granskas av redaktionen. Se www.hogreutbildning.se ISSN 2000-7558

(C2017 Jennie Sivenbring. This is an Open Access article distributed under the terms of the Creative Commons Attribution-NonCommercial 4.0 International License (https://creativecommons.org/licenses/by-nc/4.0/), allowing third parties to share their work (copy, distribute, transmit) and to adapt it, under the condition that the authors are given credit, that the work is not used for commercial purposes, and that in the event of reuse or distribution, the terms of this license are made clear.

Citation: Jennie Sivenbring (2017) "Kamratrespons som formativ bedömning för lärande», Högre utbildning 7, 1-12. http://dx.doi.org/10.23865/ hu.v7.903

1 Kursguide för att beteckna de dokument som tolkar och operationaliserar kursplanen åt studenterna i den aktuella utbildningen (Aldrin, 2013). 


\section{J. Sivenbring}

Kamratrespons kan betraktas som en teknik för att genom formativ bedömning utveckla kompetenser och lärande hos den som bedöms. Black och William (2009) definierar formativ bedömning som all verksamhet som ger information som kan verka framåtsyftande för att modifiera undervisning och lärande. Därmed inbegriper den både studenters lärande och den undervisande praktiken. I den frekvent citerade studien (Black \& William I998a), skriver forskarduon fram den formativa bedömningens potential för att stötta elevers lärande och utvecklandet av metakommunikativa förmågor. Poängen menar författarna, är att elever genom lärares täta och återkommande feedback skall få syn på och utveckla sitt eget sätt att lära. Den formativa bedömningens styrka ligger således $\mathrm{i}$ att den genom att tydliggöra mål och vägar att nå mål, också förändrar den pedagogiska praktiken och synen på lärandet. I en forskningsöversikt (Vetenskapsrådet, 20I5), skriver forskargruppen att den formativa bedömningen får effekt då den leder till en förändrad pedagogisk praktik och inte enbart används som redskap eller metod vid enstaka bedömningstillfällen. Formativa metoder fokuserar alltså det mellanrum som skall fyllas mellan det studenten i nuläget kan och vad den enligt målen förväntas kunna. Dann (20I4) menar att just feedback är ett sätt att fylla mellanrummet och verka för att vägen mot måluppfyllelse skall bli tydligare för både lärare och studenter. I de bästa av fall, kan ett formativt bedömande som lärande ${ }^{2}$ då komma till stånd.

Kamratrespons möjliggör snabb återkoppling och ger fler infallsvinklar på studenters arbete än vad en ensam lärare kan erbjuda en större grupp. Studenter som ger respons bidrar därmed till en kostnadseffektivitet samtidigt som de stöttar andras kunskapsproduktion och framåtskridande (Hanrahan \& Isaacs, 200I). Amhag (2013) menar att också lärare kan dra nytta av kamratresponsförfaranden, då de får mer tid för att följa lärprocessen och kan använda sig av studenternas respons som en resurs för egen återkoppling och bedömning.

En pedagogisk vinst med att ge respons är att den kan verka reciprokt. I en informationsfilm om feedback, utarbetad för studenter på yrkeslärarprogrammet påtalar språkhandledare Anette Wahlandt (2013) att kamratresponsens starkaste incitament är att den möjliggör ett dubbelt lärande. Denna reciprocitet betonas också av Topping (2005) som visar att studenter lär sig sambedöma sitt eget arbete i relation till den andras arbete och i relation till kunskapskrav (om dessa är tydliga). Förutom att författaren får respons och feedback i sitt skrivande, får den som ger respons erfarenheter att använda i sitt eget skrivande. Erfarenheten av att bedöma eller ge respons möjliggör utvecklandet av generiska kunskaper och kompetenser så som samarbete, kommunikativ kompetens, kritiskt tänkande och förmåga att göra synteser. Dessutom kan arbetet med att ge respons också utveckla just förmågan att stötta andra att utvecklas och lära mer, en kompetens som är värdefull för en blivande lärare (se Wahlandt 20I3; McGarr \& Clifford, 20I3). Fördelarna för den som bedömer och ger respons diskuteras av Snowball och Mostert (2013) som visar att arbetet med att ge respons upplevs som mer lärorikt än att få respons. Studenter uppger att de genom att bedöma och värdera andras texter, blir mer reflekterande och analytiska då det gäller utveckling av sitt eget skrivande.

\section{KAMRATRESPONSENS MÖJLIGA FALLGROPAR}

Tidigare studier visar att kamratrespons generellt är mest fruktbart som verktyg senare under utbildningstiden. Oerfarna studenter förefaller fokusera mer på det synliga, som till exempel

2 Det finns en distinktion mellan bedömning av lärande, bedömning för lärande och bedömning som lärande. Det senare är vad Dann (20I4) förespråkar, vanligen uttryckt som Aal - assessment as learning. 
på tekniska aspekter, form och stil - på bekostnad av innehållet (Hanrahann \& Isaacs, 20oI; van den Berg, Admiraal \& Pilot 2006). Detta tenderar att förändras då studenterna blir mer bekanta och införstådda med förväntningar och det specifika innehåll deras utbildning syftar till.

Kamratresponsens produktiva utfall har visat sig bero till stor del på hur den implementerats och vilken attityd studenterna har till att ge och ta respons till och av sina kamrater (Snowball \& Mostert, 2013). Det är också av betydelse att instruktioner om hur respons och feedback går till tydliggörs för studenterna.

Den bedömningskultur studenterna är formade i och av samt deras attityder och inställningen till bedömning påverkar också syftet med formativ bedömning för lärande (McGarr \& Clifford, 20I3). Tidigare studier (Hanrahan \& Isaacs, 200I; Snowball \& Mostert, 20I3) visar att det är vanligt att studenter anser att respons tar för mycket tid och att det inte tas på allvar av kamrater. Responsens möjligheter att verka formativt kan då bli beroende av hur relationerna i gruppen ser ut. Sociala aspekter av kamratbedömning problematiseras även av Topping (2005), som belyser hur sociala relationer i kombination med att studenter antar en lärarposition, spelar in särskilt då bedömningarna är summativa, vilket tenderar att resultera i att alla bedöms som "medelpresterande". Vidare menar Topping att även om formativ och kvalitativ feedback är mer kognitivt utmanande, är den mer socialt bekväm och framför allt mer användbar för den som får respons (än den summativa), samtidigt som den ger metakognitiva vinster för båda parter.

Sammanfattningsvis kan kamratrespons, om den implementeras omsorgsfullt och företrädelsevis senare i utbildningen vara ett verksamt och effektivt sätt att arbeta för att nå ett utökat lärande också bredvid de mål som själva uppgiften syftar till. Således kan både den som ger respons och den som tar emot, tillägna sig generiska kunskaper som en synergieffekt av responsarbetet. Den kan användas i formativt syfte för att peka ut hur kamrater kan arbeta vidare för att utveckla olika aspekter av sina texter. Kamratresponsen är mer ekonomiskt kostnadseffektiv än lärar-feedback och studenter kan förvänta sig mer detaljerad respons av en kamrat än av en lärare som skall bedöma ett stort antal arbeten inom ramen för begränsade undervisningstimmar.

\section{GENOMFÖRANDE - KAMRATRESPONS IN ACTION}

För att studera vilket lärande som möjliggörs genom kamratrespons, analyserades I6 avidentifierade responstexter skrivna av studenter på lärarprogrammets första termin. Således begagnas en fallstudiemetodik där empiriska data används för att exemplifiera och diskutera kamratrespons i en avgränsad kontext (Cohen, Manion \& Morrison 20II).

De analyserade texterna är utformade som respons på en grundtext där studenten i egenskap av lärare och myndighetsutövare förväntas lösa ett fall. En förutsättning för att lösa fallet är att studenten använder sig av skolans styrdokument och för verksamheten aktuella lagar samt fyra styrmodeller hämtade från kurslitteraturen. Det finns således fyra olika tillvägagångssätt för studenterna att förhålla sig till fallet i grunduppgiften. Samtliga studenter löser samma fall och har goda möjligheter att sinsemellan och med lärare, diskutera möjliga lösningar under ett seminarium. Grundtexterna fördelas slumpmässigt till studenten som skriver den respons som sedan laddas upp på det gemensamma nätverket. Till momentet kamratrespons, finns detaljerade anvisningar i kursguiden (bilaga I). Dessa anvisningar fokuserar respons på så väl grundtextens innehåll som form.

De responstexter som analyserats har valts ut genom ett slumpmässigt urval där var femte text $\mathrm{i}$ två icke alfabetiskt ordnade listor har plockats ut för analysens räkning. Studenterna har gett muntlig tillåtelse att texterna används, med löfte om att de avidentifierats och enbart använts 


\section{J. Sivenbring}

i detta syfte. Varje text har ett omfång på en till två sidor. De flesta är skrivna i löpande text, någon har punktat upp sin respons medan någon annan har kategoriserat sin respons som: positiv kritik respektive negativ kritik.

Som ett första steg $\mathrm{i}$ analysen, studeras de formativa formuleringarna som studenterna ger varandra i texterna. Det är således fråga om en deduktiv kvantitativ innehållsanalys där kategoriseringen av responsen förenklar en vidare tolkning av informationen (Merriam, I988). Jag menar att det fokus studenterna har i sin formativa feedback, talar om vilka förväntningar som kan vara rimliga i ett tidigt skede av utbildningen. Förutom denna kategorisering har jag i nästa steg också induktivt analyserat studenternas argument och motiv för respons. Detta görs med bakgrund i Toppings (2005) tes om att den formativa feedbacken skulle vara mer socialt bekväm, vilken utmanar min tanke om att det också kan vara socialt obekvämt att ge respons till en ny eller ännu obekant kurskamrat.

\section{Formativa formuleringar $i$ kamratresponsen}

För att finna ut vad studenterna fokuserar på har formuleringar som kan betecknas som formativa och framåtsyftande, lyfts ut och kategoriserats. Det är formuleringar som ger tydliga råd för hur texten i nästa steg kan förändras t.ex. kan du flytta om första stycket (byta plats) så det blir mer sammanhängande? Först beskrivning och sedan agerande (text B). Dessa formuleringar, har sedan kategoriserats utifrån vad de fokuserar. Kategorierna baseras på Snowball och Mosterts (20I3) analyser av kamratrespons. Denna kategorisering stämmer väl överens med de anvisningar studenterna har att tillgå $\mathrm{i}$ kursguiden (bil.I).

Det finns en överrepresentation (3I/72) av kommentarer kring struktur och organisering av texten. Vanligen handlar det om tips om hur kamraten kan ändra ordningen på texten för att lämna utrymme åt det väsentliga, få en mer tydlig argumentation och mer läsvänlig text. För att göra plats àt detta föreslår jag att inledningen och presentation av fallen tas bort, med så lite utrymme att skriva behöver detta inte finnas med och alla som läser texten känner till förutsättningarna redan (text A). Det kan också handla om rubriker och rubriknivåer, eller delar av texten som saknas. Det är troligt att studenterna med sina egna texter i åtanke har en idé om hur organisering och struktur bäst framträder. Detta motsvarar främst de första förslagen i anvisningarna för hur kamratresponsen kan utföras: om författaren har förstått frågan och besvarat hela frågeställningen (se bil.I). Detta är troligen lätt att utläsa, och ges därför utrymme i responsen. Ämnesinnehållet ges relativt lite utrymme (8/72), liksom konstaterat av t.ex. Hanrahan \& Isaacs (200I) får innehållet stå tillbaka för det som lättast synliggörs. I kommentarerna angående formalia och referenser (18/72), hänvisar studenterna till anvisningar i kursguiden och textens omfång och formatering. $D u$ borde kanske ha läst lite mer noggrant instruktionerna som står $i$ kursguiden om vad som kräus $i$ uppgiften mer exakt, och $i$ vilken ordning den skall vara. Till exempel har du missat skriva ditt namn $i$ överskrift (text L). Även här är det synliga i fokus: radavstånd, punktstorlek, sidantal och rubriksättning berörs. I de fall responsen berör referenshantering handlar det om referensens placering $\mathrm{i}$ texten och hanterandet av sekundärkällor. I något fall anmodas studenterna använda sig av styrdokumenten som en viktig källa för att styrka sitt resonemang. I de kommentarer som berör språk och stil (15/72) uppmanas medstudenter ofta att läsa om sin text, eller låta någon annan läsa den för att finna språkliga misstag Sista sidan är svår att hänga med i. läs igenom sista sidan lugnt så förstår du vad jag menar (text $\mathrm{O}$ ). De formativa råden kan också vara att studenten skall använda stavningsfunktioner i ordbehandlingsprogram, eller försöka använda ett mer akademiskt språkbruk för att vinna trovärdighet. 
Sammanfattningsvis framträder kamratresponsen som i huvudsak fokuserande på mer ytliga aspekter av kamraternas texter. Innehållet berörs endast i liten grad, vilket kan förklaras av att studenterna är så pass nya på sin utbildning att de ännu har liten erfarenhet av dels det akademiska arbetet i utbildningen, dels av den praktik deras utbildning berör. De har så att säga lite eller ingen praktisk erfarenhet av att befinna sig i den position (lärarens) som uppgiften råder dem att anta $\mathrm{i}$ lösandet av fallet. Den teoretiska positionen gör att studenterna tvingas att resonera tämligen instrumentellt utifrån tillgänglig litteratur. Diskussionen om innehållet uteblir därmed då också respondenten i regel saknar beprövad erfarenhet (se Dimenäs m.fl. 20I2). Det faktum att studenterna själva kan vara osäkra på att de själva löst fallet korrekt kan givetvis också föranleda en viss ängslan över att ge respons på detta. Responsarbete som fokuserar yta och form blir då ett säkrare alternativ där responsgivaren inte riskerar att förlora ansiktet. Dock får många texter formativa uppmaningar som berör flera olika delar av textproduktionen, således finns det goda möjligheter till formativt lärande. För att utföra responsen behöver respondenten använda kunskaper och kognitiva förmågor på de högre nivåerna i Blooms taxonomi (Krathwohl, 2002). Att bedöma och ge feedback kräver att läsaren tillämpar teorier och antaganden samt analyserar och utvärderar innehållet gentemot mål-domäner. De metakommunikativa förmågorna som Black och Williams (1998b) skriver fram som incitament för att använda formativ bedömning för lärande, kan tänkas få störst verkan på den som ger respons. Genom att hen nödgas analysera respondentens text i relation till det angivna fallet, kursguidens anvisningar, gentemot litteratur, formaliakrav och manual för referensskrivning, är det troligt att insikterna i detta lärande är större än för den som tar emot responsen.

\section{Motivera respons}

Anvisningarna för hur kamratresponsen kan utföras är detaljerade och talar om för studenten vad hen kan titta på i respondentens text. Trots detta framstår det vid genomläsning av texterna som om studenterna på olika vis försöker motivera och säkerhetsmarkera sina formativa formuleringar eller bedömningar. För att studera detta har jag lyft ut formuleringar som på olika vis motiverar ställningstaganden som rör medstudentens text ex Jag hade gärna sett en rubrik för varje styrmodell för att snabbare hitta i texten, men det är nog mest en personlig åsikt (text $\mathrm{H}$ ). Exemplet visar en formativ formulering som säkras genom hänvisning till att lättare navigering $i$ texten är en personlig åsikt. Analysen är här mer induktiv än i föregående del och de 65 motiveringar som identifierats i responstexterna har grupperats i kluster på basis av de logiker motiveringarna grundar sig på. Kategorierna har namngivits efter de logiker studenterna använder för att motivera sin kommentar. De 65 motiveringarna definieras i 5 kategorier som här representeras i fallande ordning - från de vanligaste till de mer sparsamt använda.

Underlätta för läsaren (3I/65): Studenterna motiverar sin feedback med att det handlar om att underlätta för läsaren. Det är kommentarer som säger att texten upplevs som rörig och läsaren önskar att respondenten lättar upp sitt språk, ser över sin meningsbyggnad eller ändrar på organiseringen. Som läsare upplever jag det lite rörigt och hade funnit det mer lättnavigerat om du hade haft underrubriker som beskriver modellerna (text C). Det kan också avse uppmuntrande kommentarer som handlar om att respondenten som läsare uppskattar texten och motiverar detta genom att bedöma transparens och tydlighet. Dessa kommentarer utgår ofta från att studenten som ger respons ser sig själv som mottagaren Jag som läser kan med den informationen du gett mig, tänka själv kring för- och nackdelar (text N). Genom att hänvisa till att ändringar kan 


\section{J. Sivenbring}

göras för att underlätta för läsaren, uppmanas skribenten att föreställa sig en fiktiv läsare. Som det är nu tycker jag författaren försvinner för mycket $i$ texten och jag önskar att egna tankar kommer fram (text A). I detta fall är läsaren "ett jag" som vill se skribentens egna tankar. Åsikten om huruvida det skall finnas ett subjektivt anslag i texterna skiftar, liksom att den tänkta läsaren antar olika skepnader. Läsaren konstrueras understundom som en som inte känner till textens syfte, som en som är välbekant med uppgiften eller som läraren som skall fälla det slutgiltiga avgörandet. Den fiktiva läsaren som konstrueras av respondenten är därmed inte nödvändigtvis densamma som skribenten haft i åtanke. Med tanke på hur frekvent läsaren används som motivation för feedbacken, kan det vara en poäng att tala om textgenre och mottagare i introduktion av uppgiften, eller i anvisningarna för kamratrespons.

Personliga motiveringar (15/65): Motiveringar för kommentarer uttrycks som personliga och säkerhetsmarkeras genom att hänvisa till tycke och smak, till exempel Men detta är min personliga åsikt snarare än en rättelse (text $\mathrm{H}$ ). Studenter kan också påvisa ett problem eller något de anser är ett fel och samtidigt skriva fram att de själva ofta gör samma sak; detta är ett problem jag också ofta har (text J). Det kan betraktas som ett sätt att bevara jämlika sociala relationer (Topping 2005), då studenter i det här läget inte vill anta en lärarposition gentemot jämbördiga medstudenter. Att säkerhetsmarkera kan också ibland ta sig uttryck i ett trivialiserande av det personliga Då det enbart handlar om små misstag som sker, eller gånger som kanske behöver utvecklas för att få en djupare förståelse för vad du menar, kan du ta det med en klackspark (text K). Citatet visar också hur studenter kan använda uttryck som: "enbart, små, och kanske" för att markera försiktighet samtidigt som studenten påpekar att saker och ting kan utvecklas för att ge läsaren en djupare förståelse. Detta antyder att det inte alltid upplevs som socialt bekvämt att skriva fram formativa bedömningar på någon annans text. Förekomsten av personliga motiveringar, känsla och försiktighet i responstexterna kan föranleda att anvisningarna tydligare lyfter det akademiska skivandet och objektivitet i responsförfarandet - även om förfarandet naturligtvis också är en interaktiv mellanmänsklig praktik som måste tillåta social försiktighet.

Var en god student! (8/65): Det förekommer en del formuleringar i texterna där studenter försöker disciplinera eller tala om för sina kurskamrater hur de bör agera för att vara en god student. Dessa motiveringar har inslag av kamratfostran, men är också av "tips och tricks-karaktär", där responsgivaren försöker påvisa hur skribenten kan undvika underkänt betyg. Här syns formulerade varningar om att medstudenter riskerar att plagiera och att detta leder till repressalier Du får akta dig så du inte kopierar vissa meningar från litteraturen och endast byter ut ett eller två ord, då riskerar du att åka dit för plagiat (text M). Det kan förefalla mer socialt obekvämt att ta emot den (allvarliga) kritiken från en lärare än från en student. De disciplinerande formuleringarna konstruerar den goda studenten som en som förhåller sig till reglerna och till lärarens önskemål, en som uppfyller uppgiftens alla delar, behärskar formalia och som dessutom uttrycker sig korrekt. Efter att ha läst igenom texten så är det första jag lägger märke till att radauståndet inte är $\mathrm{I}, 5$ vilket var en del av uppgiften (text F). Målet för den goda studenten är att bli godkänd. Vilket kan vara en bra idé att kolla upp (språkliga och grammatiska fel) för att undvika att bli underkänd på grund av något som hade varit lätt att rätta till med lite hjälp (text A). Studenterna motiverar sina kommentarer eller råd med att hänvisa till yttre omständigheter och ramar, att framträda som en god student också i den text som skall läsas och bedömas av lärare. Det händer att studenter också hänvisar till att lärare är olika stränga, Detta (indrag eller styckesindelning) är inga stora grejer men 
något som säkert vissa lärare lägger vikt vid (text J). Att använda sig av lärare eller uppgiftens formulering som yttre motivation är förmodligen också mer socialt bekvämt och retoriskt säkrare, än att hänvisa till estetiska preferenser eller personliga ställningstaganden.

Intresseväckande (7/65): Att formulera nyfikenhet på hur resonemanget kunde utvecklats, eller uttrycka att texten gjort läsaren nyfiken eller undrande är ett sätt att försöka locka skribenten till att utveckla texten vidare, likt implicit vägledning. Jag blev nyfiken på hur du resonerar (text D) Det hade varit jätteintressant att fä veta mer om hur... (text J). Det nyfikna frågandet kan betyda att: jag förstår inte hur du tänker, jag vill veta mer eller jag får inte veta tillräckligt. Uttryckt intresse och nyfikenhet kan vara ett retoriskt tacksamt sätt att påvisa vad kamraten kan koncentrera sig på för att utveckla sin text. Att lotsa och guida utan att leda är en av de värdefulla lärarkompetenser som McGarr och Clifford (20I3) pekar mot, och som också synliggörs som en möjlig pedagogisk vinst i kamratresponstexterna. Dock bör det påpekas, (se Dimenäs m.fl. 2orz) att en erfarenhet enbart är en händelse om den inte bearbetas genom reflektion. Den generiska kommunikativa kompetensen som guidandet här kan betecknas som, blir en lärarkompetens eller erfarenhet då studenten medvetandegörs om att det är just en lotsande och guidande feedback som uppmanar att sätta läsaren i fokus och låta den få veta mer.

Frambäv det professionella - visa att du är lärare! (4/65): Det förekommer att studenterna motiverar sina bedömningar eller formuleringar med att medstudenten i sin text kan hävda sin professionalitet. Detta innefattar idén om att begagnandet av ett yrkesspråk stärker deras yrkesroll och i förlängningen kan påverka deras status som lärare. Trots att kategorin är relativt liten i det empiriska materialet, vill jag lyfta det i förhållande till ursprungstextens innehåll. Då studenterna skall lösa fallet, förväntas de anta olika förhållningssätt varav ett är ett professionellt förhållningssätt baserat på erfarenhet och kunskap om etiska och moraliska ställningstaganden i förhållande till styrdokument. Den anvisade litteraturen för uppgiften belyser vikten av att använda ett gångbart fackspråk som ett viktigt redskap i att vara en professionell lärare. Detta används här av studenterna i analysen av kamraternas texter. Att använda rätt språk är viktigt för att uppfattas som professionell och seriös (text N). Detta visar hur studenter kan tillämpa kursinnehållet på sin nuvarande praktik, något som innefattar analys och syntes på högre nivåer i Blooms taxonomi (Krathwohl, 20I2). Trots att mycket av texternas fokus placeras på det lätt synliggjorda, kan innehåll och analys anas i flera texter och studenterna börjar identifiera sig med sin framtida position som lärare. Detta är ett argument man kan använda sig av som lärare (text $\mathrm{L}$ ). Kamratresponsen kan således öppna upp för pedagogiska vinster i form av ett lärande som riktar studenters uppmärksamhet mot att börja anta ett professionellt förhållningssätt och redan sin första termin börja identifiera sig med det yrke de aspirerar på.

\section{KONKLUSION, PEDAGOGISKA VINSTER?}

Syftet med denna artikel är som tidigare nämnts att synliggöra vilka pedagogiska vinster som kan möjliggöras vid användandet av kamratrespons i högre utbildning.

En pedagogisk vinst är att kamratrespons tveklöst är kostnadseffektiv, att sextio studenter ger respons åt varandras texter är uppenbart mer ekonomiskt än att låta en enskild lärare göra det med rimlig precision och arbetsbelastning. En annan pedagogisk vinst som denna studies resultat synliggör är hur användandet av kamratrespons aktiverar det formativa lärande och det som betecknas som bedömning som lärande (Dann, 20I4) framför allt för den som utför den. Med detta 


\section{J. Sivenbring}

menar jag att studenten för det första, för att kunna bedöma, själv behöver ha god insikt i det som skall bedömas. Insikter som denna studie visar kan beröra textgenren, innehåll, form, språk och organisering. Genom att bedöma och ge kamrater adekvata råd tillämpar studenter förmågor och kompetenser och får erfarenheter de själva kan använda sig av i fortsättningen. Bedömningen blir därmed bokstavligen ett lärande i sig självt. Studenternas användande av det som de själva tillskriver den professionella lärarkompetensen är en vinst långt utöver de generiska och kommunikativa kunskaper som Wahlandt (2013) talar om. Dock behöver studenterna för att kunna ge formativ respons på innehållet, också själva förstå innehållet och se sig som tillräckligt kompetenta att göra denna bedömning.

De olika kamratresponstexterna (se tabell I) vittnar om varierande kvalitet och innehåll i den respons som ges. De är dessutom väldigt olika till sin omfattning. Uppgiften innebär att studenterna förväntas lägga ner en hel del tid och ansträngning samtidigt som de tidigt i utbildningen lägger stor vikt vid lärarens feedback i sin värdering av den insats de själva gjort. Detta också sagt i relation till vad tidigare studier (Hanrahan \& Isaacs, 200I; Snowball \& Mosterts, 20I3) belyst: att studenter anser att responsarbetet kostar mer än det smakar och att det inte alltid tas på allvar varken av mottagande skribent eller av lärare. För att responsarbetet och skrivprocessen skall ses som fruktbart och värt ansträngningen, behöver studenten i detta skede av utbildningen också få en kommentar från läraren på slutprodukten, något som visar att läraren sett processen och godkänner innehållet i relation till kursmålen.

Kamratresponsen förefaller så som Topping (2005) skriver fram den, också ha sociala aspekter som behöver tas i beaktande. I de fall där studenter ingår i olika grupper eller ännu inte är bekanta med varandra, kan det vara socialt obekvämt att lämna respons. Dessutom kan studenten riskera att förlora ansiktet om hen ger "fel respons" eller lämna felaktiga uppgifter till författaren. Ett sätt att undvika obekvämheten kan vara att så som studien visar, motivera sin respons med att hänvisa till lärares preferenser eller skrivningar i anvisningar i kursguiden. Det är då av stor betydelse att kursguiden är tydlig med vad som förväntas av studenterna. Ett annat sätt att undvika social obekvämhet är att mildra eller trivialisera sina framskrivningar genom att säkerhetsmarkera dem och hävda personliga ställningstaganden, tycke och smak eller uppmana skribenten att ta det hela med "en klackspark". Ett sätt att undvika social obekvämhet kan vara att erbjuda diskussioner och möjligheten att reflektera över hur kompetensen att ge och ta konstruktiv kritik kan bidra till utveckling av skrivandet. Det är också viktigt att tydliggöra att det finns en skillnad mellan sak och person. Det kan också vara relevant att tydligt motivera syftet med uppgiften, att se över den konstruktiva länkningen mellan mål och medel (Biggs, 1999) och tydliggöra om den är till för att ge studenterna verktyg relaterat till innehållet i kursen, eller om den främst syftar att träna studenterna i akademiskt skrivande och struktur.

Tabell I. Studenttexterna A-P samt dess fördelning över variant av respons. Text $G$ har enbart lämnat en deskription av sin medstudents text och inte gett nägra formativa kommentarer.

\begin{tabular}{|c|c|c|c|c|c|c|c|c|c|c|c|c|c|c|c|c|c|}
\hline & A & B & C & D & $\mathbf{E}$ & $\mathbf{F}$ & G & $\mathbf{H}$ & I & $\mathbf{J}$ & $\mathbf{K}$ & $\mathbf{L}$ & $\mathbf{M}$ & $\mathbf{N}$ & $\mathbf{O}$ & $\mathbf{P}$ & \\
\hline Ämnes-innehåll & & 3 & 2 & & & I & & I & & & & I & & & & & $=8$ \\
\hline 2 Struktur och organisering & 4 & 3 & 2 & 4 & I & I & & I & 2 & 6 & I & I & & I & 2 & 2 & $=3 \mathrm{I}$ \\
\hline 3 Formalia och referenser & & I & & & I & & & I & & I & & 3 & 6 & I & 2 & 2 & $=18$ \\
\hline \multirow[t]{2}{*}{4 Språk och stil } & 3 & 2 & & I & & I & & & & & 3 & I & 2 & & I & I & $=15$ \\
\hline & $=7$ & $=9$ & $=4$ & $=5$ & $=2$ & $=3$ & $=0$ & $=3$ & $=2$ & $=7$ & $=4$ & $=6$ & $=8$ & $=2$ & $=5$ & $=5$ & $=72$ \\
\hline
\end{tabular}


När Black och William (1998a; 1998b; 2009) skriver fram den formativa bedömningens fördelar pekar de, vid sidan av ökade möjligheter till lärande, också ut hur den kan förändra och utveckla den pedagogiska praktiken. Den formativa idén med feedback och respons emellan kamrater kan således tjäna syftet att också förändra den pedagogiska praktik inom vilken den äger rum. Således är det också relevant att resonera kring hur den pedagogiska praktiken kan förändras genom den information som kamratresponsen erbjuder.

En förändring eller utveckling av praktiken inbegriper implementeringen av kamratrespons i utbildningen. Studenterna som genomfört den kamratrespons som denna studie baseras på, har just påbörjat en lång lärarutbildning. Många av dem är helt nya och oerfarna vad gäller högre utbildning, en del av dem kommer direkt från gymnasiet. Bland andra Hanrahan och Isaacs (200I) påpekar att kamratrespons kan fungera bättre längre fram i utbildningen då studenterna är mer bekanta med förväntningar och utbildningens specifika innehåll. Jag hävdar mot bakgrund av denna studie att kamratrespons kan få mycket goda effekter och utfall redan tidigt $\mathrm{i}$ utbildningen. Dock bör det understrykas att utfallet och effektiviteten kräver en omsorgsfull implementering. Studenterna behöver medvetandegöras om fördelarna med kamratresponsens reciprocitet och även få öva sig i att tekniskt ta sig an uppdraget. De behöver också få verktyg för att granska och bedöma gentemot målet med uppgiften. McGarr och Clifford (2013) skriver fram att den bedömningskultur som studenterna är formad i påverkar den attityd och inställning de har till olika bedömningspraktiker. Det innebär också att det är möjligt att påverka vilken bedömningskultur de under sin utbildning kan fortsätta skolas i. Med en god implementering skulle arbetet med kamratgranskning också ge dem insikter i hur bedömning och utvärdering går till, något som många lärarstudenter upplever att de får allt för lite förberedelser för.

\section{FÖRFATTARPRESENTATION}

Jennie Sivenbring är lektor i barn- och ungdomsvetenskap på Institutionen för pedagogik kommunikation och lärande vid Göteborgs universitet. Hon är verksam inom lärar- och förskollärarutbildningens olika inriktningar och arbetar även för Segerstedtinstitutet med forskning om preventivt arbete mot rasism och extremism.

\section{REFERENSER}

Aldrin, V. (20I3). Kursguidernas roll i högre utbildning - En studie av kursguidebruk vid Göteborgs universitet. Högre utbildning, 3(I), 37-5I.

Amhag, L. (20I3). Forskning om och tillämpning av formativ bedömning för lärande. I Småberg, Thomas \& Eklöf, Anders. (2013) (red). Bedömning som motivation och utvecklande pedagogiskt verktyg; att synliggöra det synliga lärandet. Rapporter från Tankesmedjan.

Biggs, J. (1999). "What the Student Does: Teaching for Enhanced Learning". Higher Education Research \& Development I8(I), s. 57-75.

Black, P. \& William, D. (1998a). Assessment and classroom learning, Assessment in Education: Principles, Policy and Practice, 5(I), s. 7-74.

Black, P. \& William, D. (I998b). Inside the black box: raising standards through classroom assessment. Phi Delta Kappa: 8o s. I39-I48.

Black, P. \& William, D. (2009). Developing the theory of formative assessment. Educational Assessment, Evaluation and Accountability, 2I(I), 5-3I.

Cohen, L., Manion, R. \& Morrison, K. (201I). Research Methods In Education. London: Routledge.

Dann, R. (20I4). Assessment as learning: blurring the boundaries of assessment and learning for theory, policy and practice. Assessment in Education: Principles, Policy \& Practice. 21(2). I49-166. 


\section{J. Sivenbring}

Dimenäs, J., Björklund, M., Häggqvist, K., Larsson, I., Malm, A., Rundgren, M. \& Welin Mod, A. (20I2). Retorikens beprövade erfarenhet ur yrkesverksamma lärar- och sjuksköterskehandledares perspektiv. Utbildning och demokrati, 6(I), 98-II6.

Hanrahan, S. J., \& Isaacs, G. (200I). Assessing self- and peer-assessment: The students' views. Higher Education Research \& Development, 20(I), 53-70.

Krathwohl, D. (2002). A Revision of Bloom's Taxonomy: An Overview. Theory Into Practice, 4I(4), $2 \mathrm{I} 2-2 \mathrm{I} 8$.

Lärarutbildningsnämnden. (2015). Utbildningsplan för grundlärarprogrammet 180-240 HP. Göteborgs Universitet. http://lun.gu.se/digitalAssets/I508/I50867I_utbplan_grund_vtI5_webb.pdf (hämtad 2015-O2-IO)

McGarr, O. \& Clifford, A. M. (2013). 'Just enough to make you take it seriously': exploring students' attitudes towards peer assessment. Higher Education, 65, 677-693.

Merriam, S. B. (1988). Qualitative Research and Case study Applications in Education. San Francisco, CA: Jossey-Bass Publishers.

Snowball, J. D. \& Mostert, M. (2013). Dancing with the devil: formative peer assessment and academic performance. Higher Education Research \& Development, 32(4), 649-659.

Topping, K. (2005). Trends in Peer Learning. Educational Psychology: An international Journal of Experimental Educational Psychology. 25(6), 63I-645.

van den Berg, I., Admiraal, W. \& Pilot, A. (2006). Design principles and outcomes of peer assessment in higher education. Studies in higher education. 3I(3), 34I-356.

Vetenskapsrådet. (20I5). Vetenskapsrådets kartläggning av forskningsresultat med relevans för praktiskt arbete $i$ skolväsendet. Vetenskapsrådets rapporter.

Wahlandt, A. (2013). Om feedback. Göteborgs Universitet. http://gul.gu.se/public/courseId/48259/course Path/38097/ecp/lang-en/publicPage.do?item=24971495 (hämtad 2015-O2-IO) 


\section{BILAGA I. ANVISNINGAR I KURSGUIDE}

Genom att ge respons på era kurskamraters arbeten förväntas ni utveckla era analytiska färdigheter och förmågor. Övergripande handlar det om att ni ska utveckla er förmåga att värdera om författaren i sin text ger uttryck för att ha förstått innebörden i lärarens tjänstemannaskap samt skolväsendets styrning och organisation. Det handlar vid detta tillfälle också om att utveckla ert kritiska förhållningssätt och om förmågan att kunna uttrycka det muntligt genom att ge konstruktiva förslag på hur författaren kan utveckla sin text. Det handlar specifikt om att bedöma om frågan besvarats med utgångspunkt i teorier och begrepp kring styrningen av skolan, att analysera i vilken utsträckning texten ger uttryck för författarens förmåga att tillämpa dessa begrepp samt författarens förmåga att föra begripliga resonemang med en tydlig röd tråd innehållande trovärdiga argument. Även författarens förmåga att föra självständiga resonemang och förhålla sig kritiskt till litteraturen värderas. En kamratrespons består egentligen av två faser, förarbetet och själva kamratresponsen på GUL. Nedan följer förslag på frågor ni kan ställa till (er själv i läsningen av) texten under själva förarbetet och därefter några förslag på hur ni kan tänka i upplägget av kamratresponsen.

Förarbetet med förslag på frågor att ställa till texten

A) Initialt går det att ställa nedanstående tre basala formalistiska frågor till texten. Dessa är tänkta att användas för att fastställa om och i så fall $i$ vilken utsträckning frågeställningen har besvarats.

- Har författaren förstått frågan (besvaras hela frågan eller endast vissa delar av den)?

Förs det resonemang kring hur författaren skulle agera utifrån alla de fyra förhållningssätten byråkratiskt, professionellt, marknadsstyrt, brukarorienterat - eller saknas det resonemang kring (alla eller) något av de fyra förhållningssätten?

Förs det en/flera diskussioner kring alla de fyra förhållningssättens för- och nackdelar i hanteringen av fallet, eller saknas det diskussioner kring något (eller alla) förhållningssätten? Lyfts det osystematiskt fram endast fördelar kring ett förhållningssätt och endast nackdelar kring ett annat?

- Besvaras frågan med utgångspunkt i litteraturen?

Vad finns det för förankring i kurslitteraturen (Fredriksson 20IO)? Saknas den helt eller saknas den avseende vissa delar och vad innebär det i så fall för dig som ska värdera om författaren i sin text förstått innebörden i lärarens tjänstemannaskap samt skolväsendets styrning och organisation?

- Ger författaren uttryck för en teoretisk förståelse för de begrepp som används?

Finns det i texten någon definition eller karaktärsbeskrivning av centrala begrepp (t ex de fyra förhållningssätten) som används, går det att bedöma karaktärsbeskrivningens trovärdighet och är definitionen eller karaktärsbeskrivningen rimlig?

B) Därefter går det att ställa nedanstående frågor till texten för att avgöra hur författaren i sin text ger uttryck för analytisk förmåga.

- Hur tillämpas de centrala begrepp som tas upp i texten?

Används de centrala begreppen mekaniskt utan att det egentligen framgår att författaren förstått dess innebörd eller exemplifierar författaren $t$ ex agerandet utifrån det byråkratiska förhållningssättet genom självständigt valda exempel samt genom att vara konkret i 


\section{J. Sivenbring}

hänvisningen till vilka specifika dokument som skulle användas och vilka skrivningar i dessa dokument det skulle kunna tas hänsyn till?

- Vilken analytisk nivå håller texten som helhet?

Jämför författaren likheter och skillnader mellan de fyra olika förhållningssätten t ex på vilket sätt det brukarorienterade förhållningssättet och det professionella förhållningssättet kan likna varandra? Argumenterar författaren trovärdigt för sina påståenden i texten genom att också lyfta fram också motargument?

C) Avslutningsvis går det också att läsa texten med fokus på dess form. Här handlar det om i vilken utsträckning det finns en röd tråd och hur tydlig den är. Hur är språket, går det att begripa vad det är författaren försöker uttrycka eller innehåller texten syftningsfel, stavfel eller annat som gör att läsaren stannar upp i sin läsning. Går det att utläsa vem som säger vad i texten eller beskriver författaren andras tankar och fakta som sina egna? Är referenshanteringen systematisk och korrekt eller saknas det hänvisningar i brödtexten som gör det svårt att identifiera varifrån författaren hämtat sina uppgifter och resonemang från? 